INTERNATIONAL JOURNAL OF SYSTEMATIC BACTERIOLOGY

Vol. 17, No. 3 July 1967

pp. $255-259$

Copyright 1967 by the Iowa State University Press

\title{
REPORT OF THE SUBCOMMIT TEE ON PSEUDOMONAS AND RELATED ORGANISMS (1962-1966)
}

The VIII International Congress for Microbiology authorized the International Committee on Nomenclature of Bacteria to set up a Subcommittee to deal with Pseudomonas and related organisms. In pursuance of the authorization Dr. J. M. Shewan was named chairman and Dr. W. C. Haynes became secretary at the end of 1962 .

Most of the year 1963 was taken up with organisation. The membership, completed on December 31, 1963 is as follows:

Shewan, Dr. James M. (Chairman), Ministry of Technology Torrv Research Station, P. O. Box 31, 135 Abbey Road, A berdeen, Scotland, U.K.

Haynes, Dr. William C. (Secretary), U.S. Department of Agriculture, Northern Utilization Research and Development Division, 1815 N. University St., Peoria, Illinois 61604, USA

Afrikian, Dr. Evrik G., Institute of Microbiology, 19 Charentz Str., Erevan, U.S.S. R.

Billing, Dr. Eve, Department of Microbiology, The University, Reading, England, U. K.

Iizuka, Dr. Hiroshi, Institute of Applied Microbiology. The University of Tokyo, Tokyo, Japan

Liston, Dr. John, College of Fisheries, University of Washington, Seattle, Washington 98105 , USA

Liu, Dr. Pinghui, Department of Microbiology, University of Louisville, Louisville, Kentucky 40208, USA

Lysenko, Dr. Oleg, Laboratory of Insect Pathology, Ceskoslovenska Akademia Ved, Praha-Dejvice, Na civicisti c.2, Czechoslovakia

Rud, Dr. Muriel E., Department of Botany, University College of Wales, Aberstwyth, Wales, U.K.

Schubert, Dr. Ralph H.W., Hygiene-Institut der Universität Bonn, Bonn-Venusberg, Germany

Starr, Dr. Mortimer P., Department of Bacteriology, University of California, Davis, California 95616, USA

Sulzbacher, Dr. William L., Eastern Utilization Research and Development Division, Beltsville, Maryland 20705, USA Véron, Dr. Michel, Laboratoire de bactériologie, Faculté de Medédine, 4, place St. Jacques, 25-Besançon, France. 
The Subcommittee on Pseudomonas and related Organisms met at 10:30 A. M. , July 21, 1966 at the Metschinikoff Institute, Moscow, U.S.S.R, Members present were J.M. Shewan (Chairman), W. C. Haynes (Secretary), E. Afrikian, Eve Billing, O. Lysenko, Muriel Rhodes, R. Schubert, M. Star $r$ and $M$. Véron.

The Subcommittee's report for the period 1962-66 was tabled.

Although it had not been possible to convene any meetings of the Subcommittee since its inception in 1963, it was fortunate that in the U.S. A. and the U.K. two groups, viz., the American Society for Microbiology's Subcommittee on the Pseudomonadales and the British 'Working Party on Pseudomonads,' on both of which some members of the International Subcommittee serve, have been actively engaged on some of the problems facing the International Subcommittee. Liaison between the two groups has been established through Dr. Eve Billing.

The British group have initiated comparative testing schemes, the second of which is now in operation.

The Subcommittee noted with appreciation the work of these groups and also the independent studies of Stanier, Mandel, and Doudoroff and their respective colleagues (vide infra) that have considerably clarified some of the problems facing the Subcommittee.

The aims and objectives of the Subcommittee were discussed at an ad hoc meeting between the Chairman (Dr. Shewan) and the American members of the Subcommittee (Drs. Haynes, Liston, Liu, Starr and Sulzbacher) during the 64 th Annual Meeting of the American Society for Microbiology in Washington, D. C. , U.S. A. in May 1964.

One of the results of this meeting was to recommend that the work of the International Subcommittee be confined initially to the study of the genus Pseudomonas. Four objectives were proposed:

1. to define the genus Pseudomonas,

2. to recommend to the International Committee on nomenclature of Bacteria the choice of neotype strains for Pseudomonas aeruginosa and $\underline{P}$. fluorescens,

3. to report on the list of named strains of Pseudomonas species known to exist in type-culture collections, and

4. to consider the list of tests used for investigation of Pseudomonas species and their possible standardization. 
Inasmuch as the American Society for Microbiology Subcommittee on Pseudomonadales had already started the task of defining the genus Pseudomonas, our Subcommittee decided to await a recommendation that would be transmitted to its members and to other national committees such as the British 'Working Party on Pseudomonads' for consideration and comments.

This recommendation, formulated by the ASM subcommittee at its meeting at Los Angeles in May, 1966, was received. The definition was based on the monographs of Stanier, Palleroni and Doudoroff (J. gen. Microbiol. 43:159 (1966)), Mandel (J. gen Microbiol. 43:273 (1966)), and Redfearn, Palleroni and Stanier (J. gen. Microbiol. 43:293 (1966)), and the unpublished work on Hydrogenomonas by Doudoroff. It was submitted to the entire membership (8) of the ASM Subcommittee on Pseudomonadales for ballots. The response was six (6) in favour and one (1) opposed.

At the Moscow meeting the Subcommittee considered, inter alia, the four objectives noted above.

\section{(1) Definition of Pseudomonas}

It was unanimously agreed that the definition of the aerobic pseudomonads be stated, on the basis of our present knowledge, as follows:

Unicellular rods with the long axis straight or curved but not helical. Motile by means of one or more polar flagella or nonmotile and atrichous. Gram-negative. Do not form spores, stalks or sheaths. The energy-yielding metabolism is respiratory, never fermentative or photosynthetic. All use molecular oxygen as a terminal oxidant and some can use denitrification, as an alternative anaerobic respiratory mechanism. All are chemo-organotrophs, and some are facultative chemo-lithotrophs. The DNA contains between 57 and 70 moles percent of guanine and cytosine. (The scientific terms used in this description are defined in the book "Microbial World" by Stanier and Doudoroff, Prentice-Hall.)

\section{(2) Types and Neotypes}

It was unanimously agreed that the strain ATCC 10145 (NCTC 10332, NCIB 8295, CCEB 481, NRRL B-771, IBCS 277, RH 815) be recommended as the neotype for $\underline{P}$. aeruginosa and that the strain ATCC 13525 (NCTC 10038, NCIB 9046, CCE B 546, RH 818, M. Rhodes $28 / 5$ ) be recommended as the neotype for $\underline{P}$. fluorescens. 
These recommendations conform to the requirement of rule 9 (d) note $c$ in the International Code of Nomenclature of Bacteria and Viruses (Iowa State College Press, Ames, 1958) and were proposed in the Int. Bull. Bact. Nomencl. Taxon. (now Int. J. Syst. Bact.). [Hugh, R. and Leifson, E. 1964. The proposed neotype strains of Pseudomonas aeruginosa (Schroeter 1872) Migula 1900. Int. Bull. Bact. Nomencl. Taxon. 14:69-84; Hugh, R., Guarraia, L. and Hatt, H. 1964. The proposed neotype strains of Pseudomonas fluorescens (Trevisan) Migula 1895. Int. Bull. Bact. Nomenl. Taxon. 14:145-155.]

\section{(3) Lists of species}

It was resolved that inasmuch as the list of type strains, working strains, etc. of the Pseudomonas species recently published in the International Journal of Systematic Bacteriology might be considered by some to have the status of approved, authentic species, no action be taken in support of this until the list is revised.

It was resolved that the list of named species of pseudomonads, including the plant pathogens, known to exist in well recognized type-culture collections and drawn up by the Torry Research Station staff be circulated to all members of the Subcommittee for comment, amendment and correction.

It was noted from the report that major culture collections had been canvassed to discover the location of strains of Pseudomonas listed by one of the names in the 7 th edition of Bergey's Manual of Determinative Bacteriology. A list was then prepared of species names which were unrepresented by cultures. A request for information and cultures of these strains was published in the November 1964 issue of ASM News. No response was received. It was concluded that there are no pure cultures existing of the following spe-

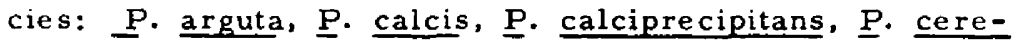
visiae, $P$. effusa, $P$. epheme rocyanea, P. erythra, P. fairmontensis, $\underline{P}$. gelatica, $\underline{P}$. iridescens, $\underline{P}$. lacunogenes, $\underline{P}$. lasia, $\underline{\text { P. marinoglutinosa, }}$ P. membranoformis, P. mira, $\underline{P}$. rugosa, $\underline{P}$. segnis, $\underline{P}$. smaragdina, $\underline{P}$. subcreta, and $\underline{P}$. tralucida. Information about them would be welcomed by the Subcommittee.

(4) Tests for characterisation of strains

It was noted from the report that a list of "Tests used for strains of Pseudomonas and related organisms" prepared 
by Dr. Margaret Thornley was sent to all members of the ASM Subcommittee on Pseudomonadales with requests for comments, criticisms and additions. In general it was reported that the list was useful as a catalogue of methods but that much comparative work needs to be done.

The Subcommittee resolved that the British 'Working Party on Pseudomonads' be encouraged to continue and to extend their comparative testing program.

Possible criteria to be used for differentiation of Pseudomonas species from those in allied genera such as Aeromonas and Vibrio were discussed. Some interesting suggestions were put forth by Drs. Véron and Schubert, and the Chairman has agreed to draw up a list of these differentiating features to be circulated to the members for their comments.

\section{(5) Future activities of the Subcommittee}

Further discussion took place on other taxa that might be considered in greater detail by the Subcommittee. It was recognized that more thought and work ought to be devoted to such genera as Acetomonas, Methanomonas, Hydrogenomonas, Flavobacterium and allied organisms.

\section{(6) Meetings of the Subcommitte}

The Subcommittee resolved that every opportunity should be taken for the members of the Subcommittee to get together as often as possible and that meetings of the entire membership should be arranged, if possible, at two-year intervals.

\section{(7) Appreciation}

The Chairman, on behalf of the Subcommittee, expressed his sincere thanks to Dr. Evrik Afrikian for the great effort he had made in arranging the meeting at the Meschinikoff Institute. The Chairman also asked Dr. Afrikian to convey to the Director and his associates at the Metschnikoff Institute the Subcommittee's appreciation for the hospitality extended to the members on the occasion of their visit and for all that was done to ensure the wellbeing of the Subcommittee during the deliberations at the Metschnikoff Institute.

26 th July 1966

James M. Shewan, Chairman William C. Haynes, Sec'y 